\title{
THIRD PARTIAL DECISION OF THE CONSTITUTIONAL COURT OF B\&H ABOUT CONSTITUTIONALITY OF PEOPLES IN BOSNIA AND HERZEGOVINA
}

Edin Djedović ${ }^{1}$

Received: 21.04.2013.

Accepted: 30.04.2013.
Review paper

UDC: $342.4: 323.1(497.6)$

\begin{abstract}
Constitutionality of the peoples is one of the most frequent terms used in the post - Dayton era of B\&H state functioning. The specificity of the existence of constituent binds to $B \& H$ and its complex constitutional organization, because the comparative law knows no such terminology. In the political sphere it was first mentioned in the process of dissolution of Yugoslavia, and in the constitutional order of B\&H enters through the Constitution of the FB\&H, and Constitution of $B \& H$. Following the adoption of the Constitution set the important question of the importance of constituent peoples in terms of whether it is a collective right to a certain cooperation or equal to the concept of sovereignty, and that it applies only to representation in state government at the state level and throughout Bosnia and Herzegovina. This is driven by the various discussions which are usually given to political connotations. The best answer to such questions is given by the Constitutional Court through the third partial Decision on Constituent Peoples, through which prism we look the meaning of the constituent peoples in $B \& H$.
\end{abstract}

Key words: constitution, constituent peoples, entities, segregation

INTRODUCTION TO THE TERM AND EVOLUTION OF IDEA ABOUT CONSTITUTIONALITY OF PEOPLES IN BOSNIA AND HERZEGOVINA

The word constitutive comes from the Latin term „constituo“ which ,as a noun means place, order and as a verb to set, to order, to place, to found (www. rjecnik.ba). From the Latin term constituo as a term of a word is derived the English word constitution. The term constituant people could be etimologically understood as ,people who make constitution“. The term constituency as an official term did not have a particular meaning in Yugoslavia, until the begining of its dissolution. In that time it started to speak more seriously about it and the term throw the political sphere slowly enters into a sphere of constitutional law. As for Bosnia and Herzegovina (further B\&H), in fact the begining of the content of constituency has already been determined by the decision of the First session of ZAVNOBIH (in a specivic way when it said that B\&H is neither Serbian, Croatian nor Mus$\mathrm{lim}$, but it is also Serbian, Muslim and Croatian), and AVNOJ, and subsequently by the Constitution of Yugoslavia and Socialist Republic of Bosnia and Herzegovina, firstely through the national participacion in the government, even through we can not observe constituency just as a single distribution of power.

However, the certain categories of constituency existed in practice for many years, this term ,was not used explicity in the constitutional documents up to the Washington Agreement and Constitution of Federation of Bosnia and Herzegovina (further FB\&H) from March 1994“" (Trnka, 2000, p. 30).

\footnotetext{
${ }^{1}$ Correspodence to:

Edin Djedović, Cantonal Administration for Inspection of Tuzla Canton

Phone: +387061 731129

E-mail: e_djedovich@hotmail.com
} 
It is interesting that it has been used in all failed peace plans for $\mathrm{BiH}$ during 1992-1994. However, with the Dayton peace Agreement, constituency will officially get the status of constitutional category in the whole B\&H.

Very important is the fact that constituency as a term enters into the domestic political - legal theory through the International community and Arbitration Committee of the Peace Conference for Yugoslavia which were answering the question „Do Serb population in Croatia and B\&H, as one of the constutient peoples of Yugoslavia, the right to self-determintion up to secession?".

Arbitration Comittee was giving advisory opinions based on the highest legal regulations of Yugoslavia and norms of international law. The basis for this opinion was Constitution of Yugoslavia adopted 21.02.1974. Arbitration Committee has carried out a proper conclusion, that constituent peoples are not sovereign, so they do not have the right to self - determination as a consequence of sovereignty but the right to a special collective recogniation and protection. In that case the Arbitration Committee, was confronted with the multi - ethnic community such as $\mathrm{B} \& \mathrm{H}$, and the issue of civil and national model, acknowledged special collective rights, in the foreground put the civil principle ${ }^{2}$.

The situation changed radically with adoption of the Constitution of B\&H in 1995 which put the national concept into foreground contrary to the Arbitration Committee opinion. Since the time of Yugoslavia dissolution, the question of the relationship of civil and national model sets an extraordinary border of the successful development of $\mathrm{B} \& \mathrm{H}$. The worst situation for $\mathrm{B} \& \mathrm{H}$ is radicalization one or the other model, because the successful way to democratic development of B\&H can be only through equality and protetion of fundamental human rights and freedom of all the citizens and people of B\&H across the entire teritory.

\footnotetext{
${ }^{2}$ In its opinion number 4 from 11.01.1992. (conditions for recognization of $\mathrm{B} \& \mathrm{H}$ ) Arbitration Comittee declares among all that ,above mentioned declarations and commintments comes from the Presidency and Government of B\&H, and that Serbian members of Presidency did not join above mentioned commintments. In such circumstances Arbitration Comittee considers expression of the will of citizens of $\mathrm{B} \& \mathrm{H}$ that SRB\&H constitutes as sovereign and independent country can not be considered totaly justified. That evaluation could be changed if in that case republic which formulated the request for recognition gave guarantiees, eventually through the referendum of all $\mathrm{B} \& \mathrm{H}$ citizens would be invited without diference and under the international control“". Avalilable on www.pescanik.net 28.08.2011.
}

\section{CONSTITUTIONAL FOUNDATION OF A TERM CONSTITUENT PEOPLES}

Constituency of peoples enters into the constitutional legal frameworks in $\mathrm{B} \& \mathrm{H}$ with the signing of the Washington Agreement respectively establishment of the FB\&H and adoption of the Constitution of FB\&H. As a model it is also adopted in the Constitution of $\mathrm{B} \& \mathrm{H}$ in a way that last decree in preamble says „Bosnians, Croats and Serbs, as constituent peoples (together with Others), and citizens of Bosnia and Herzegovina resolves that Constitution of Bosnia and Herzegovina is as follows". We could say that the Constitution of B\&H took same of the basics consociational democracy that includes functioning of the state to the full filment of certain conditions ${ }^{3}$. Through entity (and cantonal organization) maximum protection of three Bosnian collectives is ensured. Then it was a good peace, and established the basic elements neccessary for progres of B\&H through the democratization and the access to European integration. So therefore in Article 2 Paragraph 2 of the Constitution of $\mathrm{B} \& \mathrm{H}$ prescribed „In $\mathrm{B} \& \mathrm{H}$ rights and freedoms will be directly implemented, declared in European Convention for the Protection of Human Rights and Fundamental Freedoms as well as in its Protocols. This will have priority over all other laws“. Expecially important are additional agreements on Human Rights which will be applied in $\mathrm{B} \& \mathrm{H}^{4}$.

After adoption of the Constitution of $\mathrm{B} \& \mathrm{H}$, the question was raised - what the term constituent peoples mean, is it right to a collectivity to a certain cooperation or it is equal with the concept of sovereignty, and therefore applied to representation in the state government at the state level or to the whole country etc.

\footnotetext{
${ }^{3}$ Arend Lijphart considered that plural or divided societies could function only if four basic conditions should be fullfiled: 1 . the big coalition, 2. principle of veto, 3 . proportionality, 4. high level of independency; see detaly in Arend Lijpart, Democracy in Plural Societies, Zagreb 1992.

${ }^{4}$ Annex I to the Constitution of B\&H consist 14 such agreements
} 
DETERMINATION THE PEOPLES RIGHT TO CONSTITUTIONALITY WITH REGARD TO THE DECISION OF THE CONSTITUTIONAL COURT OF B\&H.

\section{The necessity of the Constitutional Court deci- sion}

The General Framework Agreement for Peace in $\mathrm{B} \& \mathrm{H}$ is aimed to stop the war and ensure peace and stability in $\mathrm{B} \& \mathrm{H}$, which was achieved. It set an important foundations of democratic development of $\mathrm{B} \& \mathrm{H}$ which are secured by establishing democratic institutions of government and the obligation to respect the international standards regarding the protection of fundamental human rights and freedoms.

The international community during the peace negotiations, and also during the whole war in the some way watched ,all the sides in war". Because of this kind of approach and need to satisfy all in a certain way, it led to a numeruos compromises that paralyzed the country and obstruct, first of all, an individual abstract $\mathrm{B} \& \mathrm{H}$ citizens protection of its fundamental human rights and freedoms, becaues of that „Constitution of $\mathrm{B} \& \mathrm{H}$ is probably the only valid constitution in the world, that at the same time prohibits and presenbes (allow) discrimination (Porobić, 2005, pp. 37-39). The Constitution of $\mathrm{B} \& \mathrm{H}$ has set a good graund that alows democratic forces and ideas that with procedures precribed by the Constutition, i.e agreement or consenzus change and build up the constitutional order of $\mathrm{B} \& \mathrm{H}$.

„It is undersstundable that in a post - conflict situation there was (and there is) not enough trust between ethnic groups to allow that government only works on the principle of majority. In such situation the specific ways of pretection has to be found to ensure that all major groups, in $\mathrm{BiH}$ that are constituent peoples, can accept the constutitional rules and feel protected by them" ${ }^{\text {"5 }}$.
„Accordingly to the extend neccesity to protect specifity of one of the groups (its identity) to the extend of civil concept of the state should give in back" (Ademović, 2006, p. 236). But now we see that the protection of collectivity is euphasized to much and thus largely threatens the rights of individuals and minority national groups, but also paralyzes functioning of the state government.

\section{Presentation of Third Partial Decision of the Constitutional Court number U-5/98}

Constitution of B\&H in a Article 12 Paragraph 2 prescribed ,within three months from the proclamation of this Constitution, the Entities will make changes of its constitutions in order to adjust with this Constitution in accordance with Article 3(3) $b^{\text {c67 }}$. This kind of constitutional, ,regulation chorly shows that the constitutions of the entities, including their total legal order been accepted with the Peace Agreement only to the extend that they are consistent with the Constitution of $\mathrm{B} \& \mathrm{H}^{\prime \prime}$ (Trnka, 2000, p. 78).

„Entities are only partially and after the set deadline made adjustment of certain regulation of its constitutions with the Constitution of $\mathrm{B} \& \mathrm{H}$, thus leaving a large number of discrepant regulations of crucial meaning for the achievement of national eguality, respecting the human rights and functioning of total law and political system, i.e. consistent implementation of the Dayton Agreement" (Trnka, 2000 , p. 78). The adequate adjustment of the entity's constitutions did not happen, then the Chairman of the Presidency of B\&H Alija Izetbegović withe the request from 12.02.1998. (after 2 years from the obligation of constitution adjustment), initiated a procedure to the Constitutional Court of $\mathrm{B} \& \mathrm{H}$ in order to evoluate the consent of the Constitution Serbian Republic and Constitution of the Federation of B\&H with the Constitution of B\&H.

${ }^{6}$ (Third) Partial Decision of the Constitutional Court of B\&H U-5/98, OG B\&H 23/00

${ }^{7}$ Article 12. Paragraph 2. of the Constitution of B\&H
Opinion of the Venice Commission (European Commission for Democracy through Law) about the constitutional situation in Bosnia and Herzegovina and the jurisdictions of the High Representative -document CDL-AD (2005) 004 of 11.03.2005. taken from the veredict Sejdic and Finci vs. Bosnia and Herzegovina application number $27996 / 06$ and $34836 / 06$ of 22.12.2009. 
The essence of his request ${ }^{8}$, in the part of peoples constituency, was reflecting in the fact that the Serbian Republic (further RS) can not be determinated as a national country of just one nation - the Serbian people, because the functioning of RS on the basis of exclusive power premented the realization of the basic rights of all displaced persons to return to their home and restored the national structure of the population, which was disrupted by the war and ethnic cleansing. The Constutition of the FB\&H also can not speak only in case of Bosniacs and Croats as constituent peoples. In this way the entities lead to discrimination of Croats and Bosniacs in RS, and Serbs in FB\&H which is contrary to Constitution of $\mathrm{B} \& \mathrm{H}$ according to there are three constituent peoples Bosniacs, Croats and Serbs which together with the others nationalities and citizens achieve its sovereign rights throughout the teritory of $\mathrm{B} \& \mathrm{H}$, without discrimination on any grounds, like for example on ethnic background.

Arguments of the parties ${ }^{9}$ on any issue were apposed. „For and against" argumentation in fact portrayed the fact that the applicant representatives defended the interests of the state $\mathrm{B} \& \mathrm{H}$, and its citizens and peoples, while the representatives of the entities were aggainst such additude, which in their opinion is the impact on entities, their original rights, the government organization and teritory, forgetting the fact that entities do not have original jurisdiction, to discriminate individuals and groups, that their territory is created on a genocide and ethnic cleansing etc. The Applicant representative pointed out that, throghout the history of B\&H ethnic criteria were never applied to the organization of government structures, nor the national teritories were an element of the constitutional order" ${ }^{\text {"10 }}$

${ }^{8}$ Applicant requested to reconsider the following norms of the entities constitutions from the Constitutuional Court:

a) Regarding the Constitution of RS: Preamble; Paragraph 1.; Article 2.; Paragraph 2., Article 4.; Article 6., Paragraph 2.; Aticle 7., Article 28., Paragraph 4.; Article 44.; Paragraph 2.;Amendment LVII.; Article 58.; Paragraph 1.; Article 68 Line 6,; Article 59.; Article 60.; Article 80 changed by the Amendment XL Line 1.; Article 80 changed by Amendment XL and L Line 2.; Article 98.; Article 138 changed by Amendments LI and LXV

b) Regarding the Constitution of FB\&H: Article I.1.(1); Article I.6 (1).; Article II.A.5.(c) changed by the Amendment VII.; Article III.1.a.; Article IV.B.7.a and Article IV.B.8

${ }^{9}$ On the public hearing the applicant were represented by Kasim Trnka and expert Džemil Sabrihafizović; House of Representatives of Federal Parliament of B\&H were represented by Mato Zovko and the expert Ivan Bender; National Assembly of RS were represented by Radomir Lukić and expert Petar Kunić

${ }^{10}$ (Third) Partial Decision, (note 5), page 36 and that , the statehood of B\&H was always based on the equality of nations, religions, cultures and people who traditionaly live on this teritory" $" 11$ and that all three peoples must be constituent throughout the whole teritory of $\mathrm{B} \& \mathrm{H}$ because of that. Countrary to that, the expert of the House of Peoples of the Federation stated that ,while writing the Washington Treaty and the Constutition of B\&H there was no idea to define a third constituent people in Federation, because if someone wanted to establish the status of three constituent peopled in the entities the name Serbian Republic would not be abstacle" 12 .

„A representative of the National Assembly of RS in the pubic hearing stated that, it does not make sense to discusion the constituent status, because it is not established anywhere in the normative part of the Constitution, as a legal principle or norm. Further, a representative of the National Asembly of RS pointed out a rework that in the last line of the Preamble of the Constitution of $\mathrm{B} \& \mathrm{H}$ does not literally stand that Bosniacs, Serbs and Croats are constituent throughout whole territory of B\&H. Addition of the term „throughout whole territory" significantly changes the meaning of entire sentence" ${ }^{\prime 13}$.

After decision that the applicant request is admissible and that the court has jurisdiction to decide about a specific question, one of the important questions arose in the process, was the question of importance of Preamble of the Constitution, and that was just because the applicant of the request believed that foundation of the right to constitutionality of Bosniacs, Serbs and Croats throught whole territory of B\&H was determinated by the last paragraph of the Preamble of the Constitution of $\mathrm{B} \& \mathrm{H}$.

\footnotetext{
${ }^{11}$ Ibid page 36

${ }^{12}$ Ibid page 37

${ }^{13}$ According to his opinion constituent status of one or two peoples in one of the entities does not mean that they are not constituent in $\mathrm{B} \& \mathrm{H}$, but on contrary: As long as one of the peoples is constituent in one of the entities, it is constituent on $\mathrm{B} \& \mathrm{H}$ at the same time, because the B\&H teritory is made of entities.

(Third) Partial decision (note 5) page 15.
} 
In contrary to that ,the representatives of the RS National Asembly pointed out that this example is the only exception to the general rule that the preamble is not part of the constitution, because the French Constitution contatins no regulations on human rights and freedoms in the normative part of the Constitution and its preamble, refering to the French Declaration of the Rights of Human and Citizens, incorporates this regulations into the Constitution. Preamble of the Constitution of B\&H therefore neither in form or content would not filfull the requirement of legal norms, so therefore culd never be used as constitutional basis for reviewing the entity's constitution" ${ }^{\text {"15. }}$. Because of that the Preamble of the Constitution of RS is not an operative part of the constitution and has no normative character. The same applies for the Preamble of the Constitution.

The Constitutional Court decided that the Preamble of the Constitution of B\&H must be considered as an integral part of the Constitution for the following reasons. Unlike the constitution of many other countries, the Constitution of $\mathrm{B} \& \mathrm{H}$ in Annex IV of the Dayton Agreement is an integral part of an international agreement. Therefore Article 31 of the Vienna Convention on the treaty law, which establishes a general principle of international law, and those principles are according to Article III/3 (b) of the Constitution of $\mathrm{B} \& \mathrm{H}$, is an integral part of legal order of $\mathrm{B} \& \mathrm{H}$ and the entities and must be applied in the interpretation of all its regulations including the Constitution of $\mathrm{B} \& \mathrm{H}^{“ 16}$. According to the formulation taken from the Article 31 paragraph 2 of the Vienna Convention the text that is being interpreted includes preamble and annexes. The same is implied for the Preamble of the Constitution of RS, but for another reason: the text of the Preamble of the Constitution of RS is modified by Amendments XXVI and LIV (,The Official Gazette of RS“" no 28/94 and 21/96) in which expressis verbis

${ }^{15}$ Ibid page 15

${ }^{16}$ Article 31. General Rule of Interpretation

1. The contract must be interpreted in good will according to the general sence which must be given in the terms of contract and their context on the basis of its case and its goal

2. In the case of contract interpretation, context considers, beside the text introduction and included additions:

a) each agreement conected with the contract which exist beetwen the members during the contract signing;

b) each instruments which is made of one or more members during the contract signing which is accepted by other members regarding to the contract instruments. states that ,these amendments are an integral part of the Constitution of RS..." ${ }^{17}$

The Constitutional Court refered to the decision of the Supreme Court of Canada ${ }^{18}$, which found that ,these constitutional principles support and sustain the constitutional text: they are the vital unstated assumptions upon the text is based on. Even though these fundamental principles are not explicity included into the Constitution by any written regulation, except in some aspects of the indirect reference in the preamble to the Constitution Act, it would be impossible to imagine our constitutional structure without them. The principles dictate main elements of the architecture of the Constitution itself, and as much are his Life Blood. The principles help in the interpretation of the text and description of spheres jurisdiction, the reach of rights and obligations and role of our political institutions“. Thus ,the principles are not purely descriptive, but also contain a powerful normative force, and are obligatory both courts and governments" ${ }^{\text {"19 }}$. „Since any regulation of an entity's constitution must be consistent with the Constitution of $\mathrm{B} \& \mathrm{H}$ including the Preamble of this constitution, the regulations of the Preamble provide the legal basis for reviewing all normative acts of a lower status respectively to the Constitution of $\mathrm{B} \& \mathrm{H}$ as long as the mentioned preamble contains constitutional principles which according to the Canadian Supreme Court, describe obligations, or the role of political institutions ${ }^{620}$. The Court evaluates that the regulations of the preamble represent a proper standard for judicial control of the Constitutional Court regarding that they are not just declarative, but they were given a ,powerful normative force" ${ }^{\text {221 }}$.

Deciding upon the request of the applicant which considers that the RS can not be denated just as a country of Serbian people, nor that just Bosniacs and Croats in the Federation should be constitutive.

\footnotetext{
${ }^{17}$ (Third) Partial Decision (note 5) page 20.

${ }^{18}$ Case „Reference re Secession of Quebec“ (1998) 2.S.C.R. paragraphs 49-54

${ }^{19}$ (Third) Partial Decision (note 5) page 23.

${ }^{20}$ Ibid page 26.

${ }^{21}$ Ibid page 26.
} 
The Court stated that ,in the Constitution of $\mathrm{B} \& \mathrm{H}$ there are no definition of a term a constituent people and that the last line of the Preamble does not include the phrase expressis verbis ,throught the whole teritory" ${ }^{\text {"22 }}$ but despite the fact that the language of the Preamble of the Constitution of $\mathrm{B} \& \mathrm{H}$ is undefined because of this lock of definition of the status of Bosniacs, Croats and Serbs as constitutent peoples it clearly marks them all as constituent peoples i.e. as nations" ${ }^{\text {"23. }}$.

Attitudes that lead to segregation predict that peoples are constituent, but Serbs in the RS, and the Bosniacs and Croats in the FB\&H. Parity participation in the institutions of $\mathrm{B} \& \mathrm{H}$ satisfies the principle of equality of nations because peoples can be equal only at the state level, but never on the entity level because „the Dayton Agreement itself accepted the territorial separation" ${ }^{\prime 24}$.

The Constitutional Court took a diferent attitude on this issue. Specifically, in the case of multinational state the representation and participation in government structures - not only as the right of individuals who belong to certain groups but also ethnic groups as such in case of collective rights - do not violate the fundamental assumptions of a democratic state, with the exception that in case like this it requires a special form of decision - making a compromise. It is neccesary to emphosize that ,the protection of cultures and ethnic groups prohibits their assimilation and there for their segregation "25.,,Therefore, there is no question that ethnic separation with territorial demarcation does not satisfies standards of a democratic state and a pluralist society based on Article I/2 of the Constitution of $\mathrm{B} \& \mathrm{H}$ in connection with third paragraph of the Preamble. Territorial arrangment therefore must not serve as an instrument of ethnic segregation but quite the contrary must please the ethnic groups with preserving linguistic pluralism and peace, in order to contribute to the integration of state and society as such" ${ }^{\text {26 } 6}$.

„In conclusio, the constitutional principle of the collective equality of the constituent peoples which arives from marking of Bosniacs, Croats and Serbs as constituent peoples prohibits any special privileges for one or two of these peoples, any kind of domination in government structures and any ethnic homogenization through the segregation based on territorial segregation“ ${ }^{627}$.„From all this comes that the Court accepted the starting point that regulations that discriminate certain constituent peoples on the entity level do not only mean a violation of the guaranted collective national rights, but also produce discrimination regarding the realization of fundamental human rights" (Trnka, 2000, p. 100), which is in contradiction with the Article 2 Paragraph 4 of the Constitution of B\&H as the fundamental and the highest general legal act in $\mathrm{B} \& \mathrm{H}$.

The Constututional Court has declared that it is indisputable that the FB\&H and RS in the Article I/ 3 of the Constutution of $\mathrm{B} \& \mathrm{H}$ recognized as a constituent elements of B\&H. However ,this recognition does not give them any kind of carte blanche. So despite the territorial arangment can not serve as a homogenization or the right to manipulation the effects of ethnic cleansing ${ }^{628}$.

Based on this kind of argumentation, the Constitutional Court adopted a partial decision which:

A)Regarding the Constitution of RS:

Constitutional Court declares the folloving regulations, or parts of regulations unconstitutional:

a) paragraphs $1,2,3$ and 5 of the Premble, compelemented by Amandements XXVI and LIV,

b) a word state of the Serbian people and Article 1 complemented by Amendment XLIV

B) Regarding to the Constutition of FB\&H

The Constututional Court declares unconstitutional the regulations of the folowing sections:

a) the words Bosniacs and Croats as constituent peoples along with the others, as well as complementation of their sovereign rights of Section I/1 (1) replaced by Amandement III“‘29.

\section{CONCLUSION}

Constitutionally guaranteed protection of national collectivity is nor opposite to the democratic principles and is known in comparative law. It is achieved through the presentation and consideration of the special national - collective interests. However, the specificity of collective protection in $\mathrm{BiH}$ is that, the constitutional regulations of entities about constituency generated the discrimination pretending to the ethnic definition and understanding of the entity.

\footnotetext{
${ }^{27}$ Ibid page 60 .

${ }^{28}$ Ibid page 61 .

${ }^{29}$ Ibid, decision dispositive
}

\footnotetext{
${ }^{22}$ Ibid page 50.

${ }^{23}$ Ibid page 52 .

${ }^{24}$ Ibid page 13

${ }^{25}$ Ibid page 57

${ }^{26}$ Ibid page 57 .
} 
If this principle would be consistently carried, it would mean that on matters of vital national interest and entity's level of government must be decided by the consensus of all three constituent peoples. The process of determining the vital national interests should be effective and identical in both entities. If those two principles are completely fullfiled the members of constituent people would feel the same security throughout the whole country of $\mathrm{BiH}$ and it would not be important in which entity a member of the constituent peoples lives. That kind of promotion of democracy returns the faith in the concept of a multi - ethnic community because the Constitutional Court says that the interrnal organization of $\mathrm{B} \& \mathrm{H}$ "should not serve as am instrument of ethnic segregation, but on the contrary must satisfy ethnic groups by the preserving the linguistsic pluralism and peace in order to contribute to the integration of state and society as such"30. The aim of this short review is to point out the importance and meaning of the Constitutional Court of $\mathrm{B} \& \mathrm{H}$ decision once again and direction which B\&H should follow, which is the opposite to the way of the High Representative intervention, this decision is "instutionalized" through the entities constitutions.

\section{REFERENCES}

Ademovic, N. (2006). Nerazumijevanje pojma "konstitutivnosti" naroda: prepreka razvoju građanske B\&H [Ilure to understand the notion of "constituent" peoples: an obstacle to the development of a civic B\&H], Dialogue, 3-4, Sarajevo.

Arbitration Commission Opinion No. 4, taken from www.pescanik.net 28.08.2011.,

Lijphart, A. (1992). Demokracija u pluralnim društvima [Democracy in Plural Societies], Zagreb: Globus.

Opinion of the Venice Commission (European Commission for Democracy through Law) about the constitutional situation in Bosnia and Herzegovina and the jurisdictions of the High Representative -document CDL-AD (2005) 004 of 11.03.2005. taken from the veredict Sejdic and Finci vs. Bosnia and Herzegovina application number 27996/06 and 34836/06 of 22.12.2009.

Pobrić, N. (2005). Etnokratski i pravnodržavni elementi u ustavnom sistemu BiH: Da li bosanskohercegovački model odgovara standardu pravne države [Ethnocratic Legal - State Elements in the Constitutional System of Bosnia and Herzegovina: Does the BH model corresponds to the standard of a legal state]. The Legal Thought, 9-10, Sarajevo.

The General Framework Agreement for Peace in Bosnia and Herzegovina - The Dayton Agreement, a brochure printed by USAID, the date and place of publication are not indicated.

(Third) Partial Decision of the Constitutional Court of Bosnia and Herzegovina U-5/98, OG. BH 23/00.

Trnka, K. (2000). Konstitutivnost naroda [Constitutionality of the people], Sarajevo: Vijeće kongresa bošnjačkih intelektualaca.

www.rjecnik.ba used 28.03.2011.

${ }^{30} \mathrm{Ibid}$, page 57. 